\title{
Kohesi Gramatikal Referensi dalam Koleksi Cerita Pendek Kompas
}

\author{
Sucia Winita, \& Syahrul Ramadhan \\ Fakultas Bahasa dan Seni, Universitas Negeri Padang, Padang \\ suciawinita@student.unp.ac.id; syahrul_r@fbs.unp.ac.id
}

How to cite (in APA Style): Winita, S., \& Ramadhan, S. (2019). Kohesi Gramatikal Referensi dalam Koleksi Cerita Pendek Kompas. Jurnal Pendidikan Bahasa dan Sastra, 19(2), 220 - 233. DOI: https://doi.org/10.17509/bs_jpbsp.v19i2.24787

Article History: Received (14 November 2018); Revised (23 February 2019); Accepted (05 Mai 2019). Journal homepage: http://ejournal.upi.edu./index.php/BS_JPBSP

\begin{abstract}
Abstrak: Penelitian ini bertujuan untuk menemukan bentuk-bentuk kohesi gramatikal referensi yang digunakan untuk membangun wacana narasi. Metode penelitian ini adalah metode deskriptif dengan bentuk penelitian yang bersifat kualitatif. Berdasarkan hasil analisis data ditemukan bahwa Bentuk kohesi gramatikal referensi yang ditemukan dalam koleksi cerita pendek Kompas Minggu 2015 edisi bulan Maret meliputi referensi persona, demonstratif, dan komparatif. Referensi persona yang ditemukan adalah referensi persona I terdiri atas aku, saya, ku-, -ku, kita, dan kami. Referensi persona II terdiri atas kamu, kau, -mu,dan kalian. Serta referensi persona III terdiri atas $i a$, dia, -nya, beliau, dan mereka. Bentuk kohesi gramatikal referensi demonstratif yang ditemukan berupa kini, sekarang, saat ini, kala itu, dulu, siang itu, sore itu, hari itu, hari ini, di sana, di sini, ke sana, ke mana, sana, ini, dan itu. Serta, satu bentuk kohesi gramatikal referensi komparatif yang ditemukan adalah seperti.
\end{abstract}

Kata kunci: kohesi gramatikal, referensi, cerpen

\section{Reference Grammatical Cohesion in Kompas Short Story Collection}

\begin{abstract}
This study aims to find reference grammatical cohesion forms used to construct narrative discourse. This research method is a descriptive method with qualitative research. Based on the results of data analysis, it was found that the reference grammatical forms of cohesion found in the March 2015 edition of Kompas Sunday's short story collection included personal, demonstrative, and comparative references. The persona reference found is person reference I consists of aku, saya, ku-, -ku, kita, and kami. The persona II reference consists of kamu, kau, -mu, and kalian. As well as reference persona III consists of $i a$, dia, -nya, beliau, and mereka. The demonstrative form of grammatical cohesion is found in kini, sekarang, saat ini, kala itu, dulu, siang itu, sore itu, hari itu, hari ini, di sana, di sini, ke sana, ke mana, sana, ini, and itu. As well, a comparative form of grammatical cohesion found is seperti.
\end{abstract}

Keywords: grammatical cohesion, reference, short story 


\section{PENDAHULUAN}

Bahasa merupakan sarana untuk berkomunikasi. Bahasa sebagai alat komunikasi dapat diwujudkan dalam bentuk lisan maupun tulisan. Dalam konteks tata bahasa, dikenal istilah wacana yang merupakan satuan bahasa tertinggi atau terbesar (Kridalaksana dalam Baryadi, 2002, p.2). Sebagai satuan bahasa yang terbesar, wacana tersusun atas unsur-unsur yang lebih kecil di bawahnya. Biasanya berupa kalimat-kalimat yang saling berkaitan. Senada dengan hal tersebut, wacana dapat didefinisikan sebagai rentetan kalimat yang berkaitan, serta menguhubungkan proposisi yang satu dengan proposisi yang lainnnya sehingga membentuk satu kesatuan yang menyebabkan terbentuknya makna yang serasi di antara kalimat-kalimat (Badudu dalam Eriyanto, 2009, p.2; Alwi et al., 1998, p.419)

Wacana dikatakan sebagai satuan bahasa tertinggi atau terbesar karena wacana dibentuk dari kalimat-kalimat yang memenuhi persyaratan gramatikal dan struktur yang utuh. Untuk menciptakan keutuhan tersbut maka bagian-bagian dari wacana harus saling berhubungan. Hubungan antarbagian dalam wacana dapat dibedakan menjadi dua jenis, yaitu hubungan bentuk yang disebut kohesi dan hubungan makna atau hubungan semantis yang disebut koherensi (Baryadi, 2002, p.17; Sumarlam dalam Wicaksono, 2017, p.308). Djajasudarma (2006, p.44) menambahkan bahwa kohesi adalah keserasian hubungan antara unsur yang satu dengan unsur yang lain dalam wacana, keserasian hubungan tersebut menciptakan pengertian yang apik atau koheren. Kohesi merujuk pada perpautan bentuk, sedangkan koherensi pada perpautan makna. Hal tersebut memperjelas bahwa pada umumnya, sebuah wacana dapat dikatakan baik apabila memiliki keduanya. Muhyidin (2012) menambahkan bahwa wacana dikatakan utuh apabila kalimatkalimat dalam wacana itu mendukung satu topik yang sedang dibicarakan, sedangkan wacana dikatakan padu apabila kalimatkalimatnya disusun secara teratur dan sistematis, sehingga menunjukan keruntutan ide yang diungkapkan melalui penada kekohesian.

Berdasarkan perwujudan lingualnya, Halliday dan Hasan (dalam Baryadi, 2002, p.17-18) membagi kohesi menjadi dua jenis, yaitu kohesi gramatikal dan kohesi leksikal. Dalam analisis wacana, segi bentuk atau struktur lahir wacana disebut aspek gramatikal wacana, sedangkan segi makna atau struktur batin wacana disebut aspek leksikal wacana (Sumarlam dalam Indrayanti, 2013). Menurut Halliday dan Hasan (dalam Rani, et al., 2004, p.94) unsur kohesi itu terdiri atas dua macam, yaitu unsur gramatikal dan leksikal. Hubungan gramatikal dapat diklasifikasikan berdasarkan bentuk bahasa yang digunakan. Hubungan gramatikal selanjutnya dibedakan menjadi referensi, substitusi, dan elips. Sedangkan hubungan leksikal dapat diciptakan dengan menggunakan bentuk-bentuk leksikal seperti reiterasi dan kolokasi.

Referen dibentuk dengan bantuan item-item leksikal. Item-item leksikal yang digunakan sebagai pembentuk referen ini meliputi pronominal, demonstratif, dan komparatif untuk referen gramatikal (Aflahah, 2012; Lubis, 1991, p.32). Pronominal sebagai ikatan kohesif (pronoun as cohesive ties). Pronominal digunakan untuk menyatakan hubungan benda dalam suatu wacana. Demonstratif sebagai ikatan kohesif (demonstrantive as cohesive ties). Piranti dapat digunakan baik secara anaforis maupun kataforis. Komparatif sebagai ikatan kohesif (comparative as cohesive ties). Kebanyakan komparatif ini digunakan untuk referen anaforis.

Berdasarkan pada pengetahuan tentang pengertian wacana yang beragam. Dapat dipahami bahwa kajian wacana pun tidak hanya menjadi bidang garapan disiplin kebahasaan saja, tetapi juga bidang psikologi, sosiologi, politik, komunikasi, sastra, dan sebagainya (Eriyanto, 2009, 
p.1). Hal tersebut memperjelas bahwa kajian wacana memiliki rentangan sudut pandang kajian yang luas. Dalam hal ini, kajian yang dilakukan adalah terhadap sebuah karya sastra berbentuk cerpen. Cerpen dipilih sebagai objek kajian dikarenakan cerpen merupakan salah satu bentuk karya sastra yang memiliki bentuk yang ringkas namun tetap menuntut tingkat kohesi dan koherensi yang tinggi agar tetap berupa satu wacana utuh. Kajian ini dimaksudkan untuk melihat peran kohesi dalam membangun cerita dalam cerpen. Selain itu, penelitian ini bertujuan untuk mengamati, serta menemukan bentuk-bentuk kohesi gramatikal khususnya referensi yang tentunya dapat memengaruhi gaya bahasa pengarang dalam menciptakan karyanya. Keahlian pengarang dalam menggunakan istilah yang lebih bervariasi pun ditentukan oleh caranya dalam mengolah bahasa yang digunakan. Peran kohesi dalam pengolahan bahasa ini tentunya sangat besar karena akanmemengaruhi ketertarikan pembaca pada gaya penulisan pengarang dan hasil karyanya.

Kajian mengenai analisis gramatikal referensi atau pengacuan terhadap karya sastra berbentuk cerpen juga dilakukan oleh Indrayanti (2013) dengan judul "Analisis Kohesi Gramatikal Pengacuan Pada Cerpen Surat Kabar Kompas Edisi Maret 2013". Berdasarkan pada pengkajian yang telah dilakukannya, dapat disimpulkan: (1) Pengacuan persona mencakup pengacuan persona I terdiri atas bentuk bebas aku, -ku, ku-, kami dan kita. Pengacuan persona II terdiri atas bentuk bebas kamu dan -mu, ia dan dia, -nya. Pengacuan persona III terdiri atas bentuk bebas mereka. (2) Pengacuan demonstratif mencakup pengacuan demonstratif waktu sekarang, dulu, tiga tahun yang lalu. Pengacuan demonstratif tempat ini, sana. Pengacuan demonstratif tempat eksplisitperon, stasiun, halte-halte, di dalam bis, halaman rumah, rumah sakit, kamar mandi,kantor polisi, gerbang rumah, restoran, tuang tamu, sungai, jembatan.(3) Pengacuan komparatif yang terdapat di dalam cerpen surat kabar kompas edisi maret 2013 terdiri atas bentuk komparatif seperti, bagai, bagaikan.

\section{METODE}

Penelitian ini merupakan penelitian kualitatif, yaitu pengumpulan data berupa kata-kata, gambar, dan bukan angka-angka. Metode yang digunakan dalam penelitian ini adalah metode deskriptif yaitu metode yang mendeskripsikan hasil temuan dalam bentuk verbal. Objek yang akan diteliti dalam penelitian ini adalah kohesi gramatikal referensi pada koleksi cerita pendek Kompas Minggu 2015 edisi bulan Maret. Sumber data penelitian ini adalah wacana cerpen dalam koleksi cerita pendek Kompas Minggu 2015 edisi bulan Maret sebanyak lima buah cerpen berjudul Saran Seorang Pengarang karya Sori Siregar, Kebohongan Itu Manis, Vardhaz̧ karya Indra Tranggono, Tepi Shire karya Tawakal M. Iqbal, Sepotong Kaki untuk. Ayah karya I Ngoman Wirata, dan Balada Cun dan Suami Barunya karya Dedi Supendra.

Teknik pengumpulan data yang digunakan dalam penelitian ini adalah teknik baca dan catat. Adapun teknik pengumpulan data yang penulis lakukan adalah: membaca teks cerita pendek, menandai bagian-bagian yang mengandung kohesi gramatikal penggantian, mengklasifikasikan data sesuai dengan rumusan masalah yang dikaji, dan mencatat seluruh bagian-bagian yang mengandung kohesi gramatikal referensi ke dalam hasil penelitian.

Teknik analisis data pada penelitian ini adalah: membaca teks cerita pendek dalam koleksi cerita pendek Kompas Minggu 2015 edisi bulan Maret yang menjadi objek kajian penelitian, mengidentifikasi penggunaan kohesi gramatikal referensi yang terdapat dalam koleksi cerita pendek Kompas Minggu 2015 edisi bulan Maret, mengelompokkan data yang menggunakan kohesi gramatikal referensi meliputi referensi persona, demonstratif, dan komparatif, data yang telah dikelompokkan kemudian dipaparkan dalam bentuk paragraf deskripsi, dan 
menyimpulkan data yang telah dipaparkan tersebut.

\section{HASIL DAN PEMBAHASAN}

Kohesi gramatikal referensi yang ditemukan dalam koleksi cerita pendek Kompas Minggu 2015 edisi bulan Maret berbentuk referensi persona, referensi demonstratif, dan referensi komparatif. Penggunaan bentuk kohesi gramatikal referensi padalima cerpen yang terdapat dalam koleksi cerita pendek Kompas Minggu 2015 edisi bulan Maret dapat dilihat pada uraian berikut ini.

\section{A. Referensi Persona}

Bentuk kohesi gramatikal referensi persona yang ditemukan dalam koleksi cerita pendek Kompas Minggu 2015 edisi bulan Maret adalah referensi persona I terdiri atas aku, saya, ku-, -ku, kita, dan kami. Referensi persona II terdiri atas kamu, kau, -mu, dan kalian. Serta referensi persona III terdiri atas ia, dia, -nya, beliau, dan mereka. Jumlah penggunaannya pada tiap cerpen terdapat pada tabel berikut ini.

Tabel 1. Jumlah Penggunaan Bentuk Kohesi Gramatikal Referensi Persona pada Cerita Pendek Kompas

\begin{tabular}{|c|c|c|c|c|c|c|}
\hline \multirow[b]{2}{*}{ No } & \multirow{2}{*}{$\begin{array}{c}\text { Bentuk } \\
\text { Referensi } \\
\text { Persona }\end{array}$} & \multicolumn{5}{|c|}{ Judul Cerpen } \\
\hline & & $\begin{array}{c}\text { Saran Seorang } \\
\text { Pengarang }\end{array}$ & $\begin{array}{l}\text { Kebohongan } \\
\text { Itu Manis, } \\
\text { Vardhazb }\end{array}$ & $\begin{array}{l}\text { Tepi } \\
\text { Shire }\end{array}$ & $\begin{array}{c}\text { Sepotong Kaki } \\
\text { Untuk Ayab }\end{array}$ & $\begin{array}{l}\text { Balada Cun dan } \\
\text { Suami Barunya }\end{array}$ \\
\hline 1 & aku & 3 & 16 & 45 & 7 & - \\
\hline 2 & saya & 1 & 10 & - & 4 & 10 \\
\hline 3 & ku- & 2 & 3 & 3 & - & - \\
\hline 4 & $-\mathrm{ku}$ & 3 & 3 & 29 & 8 & 4 \\
\hline 5 & kita & - & 4 & 2 & 2 & - \\
\hline 6 & kami & - & - & 4 & - & - \\
\hline 7 & kamu & 14 & 8 & - & 1 & - \\
\hline 8 & kau & 10 & - & - & - & 6 \\
\hline 9 & $-\mathrm{mu}$ & 10 & 6 & - & - & 4 \\
\hline 10 & kalian & - & 1 & - & - & - \\
\hline 11 & ia & 1 & 3 & 19 & - & 13 \\
\hline 12 & dia & - & - & - & 29 & 8 \\
\hline 13 & -nya & 13 & 11 & 39 & 21 & 56 \\
\hline 14 & beliau & - & 3 & - & - & - \\
\hline 15 & mereka & 8 & 4 & 5 & - & 3 \\
\hline
\end{tabular}

\section{Referensi Persona aku}

(1) "Kamu telah melihat sendiri bagaimana aku mementaskan sandiwara kematianku. Aku susun skenarionya sendiri. Aku jadi sutradaranya sekaligus produsernya. Aku rekrut para profesional dari direktur rumah sakit, dokter-dokter spesialis, pers, ahli rias, dan busana hingga para jenderal dan event organizer," ujar Tuan Grag sambil menuangkan anggur merah di gelas. Kebohongan Itu Manis, Vardhazh)

Pada penggalan cerpen (1), pronominal aku merupakan kata ganti persona pertama tunggal. Pronomina aku digunakan untuk menggantikan tokoh yang dimaksudkan pada bagian tertunjuk, yaitu mengacu pada Tuan Grag. Referensi kata $a k u$ tersebut merupakan pengacuan endofora karena acuan kata aku berasal dari teks wacana itu sendiri, serta 
merupakan pengacuan katafora karena satuan lingual aku dalam penggalan cerpen (1) tersebut mengacu pada satuan lingual yang mengikutinya.

\section{Referensi Persona Saya}

(2) Tina tersenyum. "Terserah Mak Ji. Saya hanya ingin suami saya tidak selingkuh. Semakin dia lekat, sebagus bagus, Mak Ji." (Balada Cun dan Suami Barunya)

Pada penggalan cerpen (2), pronomina saya merupakan kata ganti persona pertama tunggal. Pronomina saya digunakan untuk menggantikan tokoh yang dimaksudkan, yaitu mengacu pada tokoh Tina. Referensi kata saya tersebut merupakan pengacuan endofora karena acuan kata saya berasal dari teks wacana itu sendiri, serta merupakan pengacuan anafora karena satuan lingual saya tersebut mengacu pada satuan lingual yang mendahuluinya.

\section{Referensi Persona ku-}

(3) "Kekhawatiran itu tetap ada meskipun aku sudah melenyapkan para profesional yang terlibat dalam proyek besar sandiwara kematianku. Oya, aku punya ide. Aku akan operasi wajah. Semua sudah siap. Minggu depan kulaksanakan." (Kebohongan Itu Manis, Vardhazh)

Pronomina ku- dalam penggalan cerpen (3) merupakan kata ganti persona pertama tunggal. Pronomina ku- yang digunakan mengacu pada tokoh Tuan Grag. Referensi personaku- tersebut merupakan pengacuan endofora karena acuan $k u$-berasal dari teks wacana itu sendiri, khususnya terletak pada paragraf sebelumnya, serta merupakan pengacuan anafora karena satuan lingual ku-mengacu pada satuan lingual yang mendahuluinya.

\section{Referensi Persona $-k u$}

(4) "Kemarin, kau menyuruhku bercerai dengan suamiku. Sekarang, bagaimana rasanya jika suamimu jadi suamiku, Ni Cun."
Mata Inga berkaca-kaca. Senyumnya selebar dunia. (Balada Cun dan Suami Barunya)

Pronomina $-k u$ yang terdapat di dalam penggalan cerpen (4) merupakan kata ganti persona pertama tunggal. Pronomina -kumengacu pada tokoh Inga. Referensi persona $-k u$ tersebut merupakan pengacuan endofora karena acuan -ku berasal dari teks wacana itu sendiri, serta merupakan pengacuan katafora karena satuan lingual -kutersebut mengacu pada satuan lingual yang mengikutinya.

\section{Referensi Persona kita}

(5) "Persis!" katanya, sambil memperhatikan bentuk kaki palsu dari kayu bentawas buatanku. Tapi ketika dia menimang-nimang, "Agak berat," katanya. Kita coba pasang engselnya dan kalep kulitnya. Dia senang dengan kaki palsu kayu pertama buatanku. (Sepotong Kaki untuk Ayah)

Pada penggalan cerpen (5), pronomina kita merupakan kata ganti persona pertama jamak. Pronomina kita digunakan untuk menggantikan tokoh yang dimaksudkan, yaitu mengacu pada tokoh Aku dan Ayahnya. Referensi kata kitatersebut merupakan pengacuan endofora karena acuan kata kita berasal dari teks wacana itu sendiri, serta merupakan pengacuan anafora karena satuan lingual kita mengacu pada satuan lingual yang mendahuluinya, yaitu terdapat pada paragraf yang mendahului penggalan cerpen (5).

\section{Referensi Persona kami}

(6) Tiba-tiba saja tukang sapu itu berteriak pada pohon di depannya. Sungai kali ini sangat sepi. Sebab masih terlalu pagi tampaknya untuk orang-orang dating kemari hanya sekadar mengobrol dan mengambil gambar. Biasanya siang menjelang sore sungai ini mulai ramai. Di sungai ini jelas hanya ada kami 
berdua. Aku dan tukang sapu itu. (Tepi Shire)

Pada penggalan cerpen (6), pronomina kami yang merupakan kata ganti persona pertama jamak digunakan untuk menggantikan tokoh yang dimaksudkan, yaitu tokoh Aku dan Tukang sapu. Referensi kata kami tersebut merupakan pengacuan endofora karena acuan kata kami berasal dari teks wacana itu sendiri, serta merupakan pengacuan katafora karena satuan lingual kami tersebut mengacu pada satuan lingual yang mengikutinya.

\section{Referensi Persona kamu}

(7) Tuan Grag menggeleng. "Aku ingin jadi dirimu. Aku ingin ikut mengendalikan pemerintahan di negara kita. Kamu keberatan?"

Darah Vardhazh berdesir. "Tentu tidak, Tuan...." (Kebohongan Itu Manis, Vardhazh)

Pronomina kamu pada penggalan cerpen (7) yang merupakan kata ganti persona kedua tunggal mengacu pada tokoh Vardhazh. Referensi kata kamu tersebut merupakan pengacuan endofora karena acuan kata kamu berasal dari teks wacana itu sendiri, serta merupakan pengacuan katafora karena satuan lingual kamu tersebut mengacu pada satuan lingual yang mengikutinya.

\section{Referensi Persona kau}

(8) “Tapi, tenang saja," katanya lagi. "Tak ada masalah yang tak bisa diselesaikan oleh Mak Ji-mu ini. Apa kau mau suamimu dibuat seperti kerbau yang dicucuk hidungnya?" Mak Ji berbesar dada guna membesarkan hati Tina. Jika si pasien menatap matanya, maka ia akan melihat padang luas hijau, dengan angina sepoi-sepoi membelai rumput-rumput. (Balada Cun dan Suami Barunya)
Pada penggalan cerpen (8), pronomina kau merupakan kata ganti persona kedua tunggal. Pronomina kau digunakan untuk menggantikan tokoh yang dimaksudkan, yaitu mengacu pada tokoh Tina. Referensi kata kau tersebut merupakan pengacuan endofora karena acuan kata kau berasal dari teks wacana itu sendiri, serta merupakan pengacuan katafora karena satuan lingual kaumengacu pada satuan lingual yang mengikutinya.

\section{Referensi Persona -mu}

(9) Terlalu banyak saranku kepadamu. Jangan-jangan ini melemahkan hasratmu untuk menjadi pengarang. Kalau itu yang terjadi alangkah berdosanya aku. Karena itu kusudahi di sini, Radit. Selamat mengarang. (Saran Seorang Pengarang)

Pada penggalan cerpen (9), pronomina -mu merupakan kata ganti persona kedua tunggal. Pronomina $-m u$ digunakan untuk menggantikan tokoh yang dimaksudkan, yaitu mengacu pada tokoh Radit yang sedang dinasihati oleh tokoh Aku yang merupakan seorang pengarang. Referensi $-m u$ tersebut merupakan pengacuan endofora karena acuan -mu berasal dari teks wacana itu sendiri, serta merupakan pengacuan katafora karena satuan lingual $-m u$ tersebut mengacu pada satuan lingual yang mengikutinya.

\section{Referensi Persona kalian}

(10) "Saya tidak suka anarki! Kepada adik-adik mahasiswa saya pesan, hentikan semua hujatan dan makian jika kalian tidak ingin bobok manis di sel tahanan," ujar Vardhazh. (Kebohongan Itu Manis, Vardhazh)

Pada penggalan cerpen (10), pronomina kalian merupakan kata ganti persona kedua jamak. Pronomina kalian diperuntukkan untuk menggantikan tokoh yang dimaksudkan, yaitu mengacu pada tokoh adik-adik mahasiswa yang 
melakukan demonstrasi pada upacara kematian Tuan Grag. Referensi kata kalian tersebut merupakan pengacuan endofora karena acuan kata kalian berasal dari teks wacana itu sendiri, serta merupakan pengacuan anafora karena satuan lingual kalian tersebut mengacu pada satuan lingual yang mendahuluinya.

\section{Referensi Persona ia}

(11) Ketika muda ia pernah mengalami kenangan pahit, bersama teman lainnya menjadi buronan perang. Temantemannya tertangkap oleh musuh. Kata kakek hanya ia yang selamat. (Tepi Shire)

Pada penggalan cerpen (11), pronomina ia merupakan kata ganti persona ketiga tunggal. Pronomina ia digunakan untuk menggantikan tokoh yang dimaksudkan, yaitu mengacu pada tokoh Kakek. Referensi kata ia tersebut merupakan pengacuan endofora karena acuan kata ia berasal dari teks wacana itu sendiri, serta merupakan pengacuan anafora karena satuan lingual ia tersebut mengacu pada satuan lingual yang mendahuluinya.

\section{Referensi Persona dia}

(12) Aku memilih untuk tidak peduli terhadap tingkah tukang sapu itu. Di tanah ini, aku diajarkan untuk mulai tidak peduli terhadap sesuatu hal yang bisa membuat rugi. Dalam posisi ini akau akan dirugikan bila aku memerdulikannya. Pekerjaanku akan abai dan dia akan merasa menang, sebab telah mampu menarik perhatian. (Tepi Shire)

Pada penggalan cerpen (12), pronomina dia merupakan kata ganti persona ketiga tunggal. Pronomina diadigunakan untuk menggantikan tokoh yang dimaksudkan, yaitu mengacu pada tokoh Tukang sapu. Referensi kata dia tersebut merupakan pengacuan endofora karena acuan kata diaberasal dari teks wacana itu sendiri, serta merupakan pengacuan anafora karena satuan lingual dia tersebut mengacu pada satuan lingual yang mendahuluinya.

\section{Referensi Persona -nya}

(13) Pengarang muda yang masih merasa dirinya perlu banyak belajar itu mengangguk lagi. Ini yang membuat Ikra senang. Pendapat dan sarannya pun mengalir dan melimpah-ruah tidak tertahan.(Saran Seorang Pengarang)

Pada penggalan cerpen (13), pronomina -nya merupakan kata ganti persona ketiga tunggal. Pronomina -nya digunakan untuk menggantikan tokoh yang dimaksudkan, yaitu mengacu pada tokoh Ikra seorang pengarang yang sudah berpengalaman. Referensi -nya tersebut merupakan pengacuan endofora karena acuan -nya berasal dari teks wacana itu sendiri, serta merupakan pengacuan anafora karena satuan lingual -nya tersebut mengacu pada satuan lingual yang mendahuluinya.

\section{Referensi Persona beliau}

(14) Istri keempat Tuan Grag, Nyonya Zabathini yang berusia sekitar 35 tahun dan cantik itu, kepada para wartawan bilang bahwa pihak keluarga harus memenuhi pesan dari suaminya agar membuat pesta ketika Tuan Grag meninggal. "Kematian harus dirayakan karena kematian adalah kemenangan mengatasi waktu menuju keabadian, begitu kata Tuan Grag saat beliau selesai menjalani operasi jantung yang ternyata gagal...," ucap Nyonya Zabathini terisak. (Kebohongan Itu Manis, Vardhazh)

Pronomina beliau yang terdapat dalam penggalan cerpen (14) merupakan 
kata ganti persona ketiga jamak. Pronomina beliauyang digunakan dimaksudkan utnuk menggantikan tokoh yang mengacu pada tokoh Tuan Grag. Referensi kata beliau tersebut merupakan pengacuan endofora karena acuan kata beliau berasal dari teks wacana itu sendiri, serta merupakan pengacuan anafora karena satuan lingual beliau tersebut mengacu pada satuan lingual yang mendahuluinya.

\section{Referensi Persona mereka}

(15) "Kalau kamu tetap ingin dikelompokkan sebagai avant-garde boleh saja. Cuma kalau kamu tidak berhasil, jangan kecewa atau berhenti mengarang. Banyak pengarang muda yang juga mati muda. Maksudnya, setelah merasa tidak berhasil menjadi tokoh penting dalam sastra Indonesia, mereka berhenti menulis." (Saran Seorang Pengarang)
Pada penggalan cerpen (15), pronomina mereka merupakan kata ganti persona ketiga jamak. Pronomina mereka digunakan untuk menggantikan tokoh yang dimaksudkan, yaitu mengacu pada pengarang muda yang dinilai seringkali mudah putus asa dalam mengarang ketika tidak berhasil menjadi tokoh penting dalam sastra Indonesia. Referensi kata mereka tersebut merupakan pengacuan endofora karena acuan kata mereka berasal dari teks wacana itu sendiri, serta merupakan pengacuan anafora karena satuan lingual mereka tersebut mengacu pada satuan lingual yang mendahuluinya.

\section{B. Referensi Demonstratif}

Bentuk kohesi gramatikal referensi demonstratif yang ditemukan dalam koleksi cerita pendek Kompas Minggu 2015 edisi bulan Maret berupa kini, sekarang, saat ini, kala itu, dulu, siang itu, sore itu, hari itu, hari ini, di sana, di sini, ke sana, ke mana, sana, ini, dan itu. Jumlah penggunaannya pada tiap cerpen terdapat pada tabel berikut ini.

Tabel 2. Jumlah Penggunaan Bentuk Kohesi Gramatikal Referensi Demonstratif Pada Cerita Pendek Kompas

\begin{tabular}{ccccccc}
\hline & & \multicolumn{5}{c}{ Judul Cerpen } \\
\cline { 3 - 7 } No & $\begin{array}{c}\text { Bentuk } \\
\text { Referensi } \\
\text { Demonstratif }\end{array}$ & $\begin{array}{c}\text { Saran Seorang } \\
\text { Pengarang }\end{array}$ & $\begin{array}{c}\text { Kebohongan Itu } \\
\text { Manis, } \\
\text { Vardhazh }\end{array}$ & $\begin{array}{c}\text { Tepi } \\
\text { Shire }\end{array}$ & $\begin{array}{c}\text { Sepotong Kaki } \\
\text { Untuk. Ayah }\end{array}$ & $\begin{array}{c}\text { Balada Cun dan } \\
\text { Suami Barunya }\end{array}$ \\
\hline $\mathbf{1}$ & Kini & - & - & 1 & 1 & 1 \\
\hline $\mathbf{2}$ & Sekarang & 1 & - & - & - & 1 \\
\hline $\mathbf{3}$ & Saat ini & 1 & - & - & - & - \\
\hline $\mathbf{4}$ & Kala itu & - & - & 1 & - & - \\
\hline $\mathbf{5}$ & Dulu & - & - & - & 1 & 1 \\
\hline $\mathbf{6}$ & Siang itu & - & - & - & - & 1 \\
\hline $\mathbf{7}$ & Sore itu & - & - & - & - & - \\
\hline $\mathbf{8}$ & Hari itu & - & - & - & - & - \\
\hline $\mathbf{9}$ & Hari ini & - & - & 1 & - & - \\
\hline $\mathbf{1 0}$ & Di sana & - & - & - & 3 & - \\
\hline $\mathbf{1 1}$ & Di sini & - & - & 2 & - & - \\
\hline $\mathbf{1 2}$ & Ke sana & - & - & 1 & 1 & - \\
\hline $\mathbf{1 3}$ & Ke mana & - & - & - & 1 & 1 \\
\hline $\mathbf{1 4}$ & Sana & - & - & 1 & - & - \\
\hline $\mathbf{1 5}$ & Ini & - & 2 & 15 & - & - \\
\hline $\mathbf{1 6}$ & Itu & 1 & 1 & 3 & 1 & \\
\hline
\end{tabular}




\section{Referensi Demonstratif kini}

(16) Perang memang selalu menyisakan kepedihan. Meski begitu, memenangkan perang selalu menjadi impian banyak orang. Kemenangan dirasa lebih nikmat. Meski sesudahnya, kepedihan tengah menanti. Sebab kepedihan setelah perang tidak akan pernah dikenang meski tengah dirasakan. Tetapi kemenangan, selamanya akan terus dikenang. Tiba-tiba saja ingatan mengenai pertanyaan yang tertera dalam buku sejarah yang pernah kubaca itu muncul. Tak satupun orang di Woodyshire memungkiri itu. Meskipun kini kondisi mereka sedang dalam keadaan pedih. Kenangan terhadap kemenangan peranglah yang mampu membuat masyarakat Woodyshire tetap kuat. (Tepi Shire)

Pada penggalan cerpen (16) terdapat bentuk referensi demonstratif kini. Kata keterangan tersebut digunakan untuk menunjukan waktu, yaitu pasca peperangan, meskipun kemenangan telah berada di pihak masyarakat Woodyshire namun duka kehilangan orang-orang yang wafat dalam peperangan tersebut tetap menyisakan luka di hati mereka. Kata keterangan waktukini pada penggalan cerpen (16) merupakan pengacuan endofora karena acuan kata keterangan tersebut berasal dari dalam teks itu. Selanjutnya, pengacuan kata kini pada penggalan cerpen (16) bersifat anaforis karena satuan lingual mengacu pada satuan lingual yang mendahuluinya.

\section{Referensi Demonstratif sekarang}

(17) "Kemarin, kau menyuruhku bercerai dengan suamiku. Sekarang, bagaimana rasanya jika suamimu jadi suamiku, Ni Cun." Mata Inga berkaca-kaca.
Senyumnya selebar dunia. (Balada Cun dan Suami Barunya)

Pada penggalan cerpen (17) terdapat bentuk referensi demonstratif sekarang. Kata keterangan tersebut digunakan untuk menunjukan waktu, yaitu pada saat itu ketika Inga mengatakan kepada Cun bahwa suami Cun akanmenjadi suaminya.Kata keterangan waktu sekarang pada penggalan cerpen (17) merupakan pengacuan endofora karena acuan kata keterangan tersebut berasal dari dalam teks itu. Selanjutnya, pengacuan kata sekarang pada penggalan cerpen (17) bersifat kataforis karena satuan lingual mengacu pada satuan lingual yang mengikutinya.

\section{Referensi Demonstratif saat ini}

(18) Seperti halnya kamu, saat ini banyak muncul pengarang muda. Mereka tidak peduli apakah disebut sastrawan dan kontemporer atau tidak. Merekaterus berkarya. (Saran Seorang Pengarang)

Pada penggalan cerpen terdapat bentuk referensi demonstratif saat ini. Kata keterangan tersebut digunakan untuk menunjukan waktu, yaitu tahun 2015 ketika Ikra sebagai seorang pengarang senior mengatakan bahwa pada tahun tersebut banyak muncul pengarang muda yang tidak mempedulikan sebutan bagi mereka, apakah itu sastrawan dan kontemporer atau pun tidak. Kata keterangan waktu saat ini pada penggalan cerpen (18) merupakan pengacuan endofora karena acuan kata keterangan tersebut berasal dari dalam teks itu. Selanjutnya, pengacuan kata saat ini pada penggalan cerpen (18) bersifat kataforis karena satuan lingual mengacu pada satuan lingual yang mengikutinya.

\section{Referensi Demonstratif kala itu}

(19) Meskipun umumnya tentang kekejaman perang. Di sungai ini ribuan manusia korban perang 
pernah dihanyutkan. Kala itu bau amis darah, air merah, dan kicauan burung bangkai menjadi sebuah fenomena yang biasa. (Tepi Shire)

Pada penggalan cerpen terdapat bentuk referensi demonstratif kala itu. Kata keterangan tersebut digunakan untuk menunjukan waktu, yaitu mengacu pada masa lampau ketika ribuan manusia korban perang dihanyutkan di sungai Shire sebagai bentuk dari kekejaman perang. Kata keterangan waktu kala itu pada penggalan cerpen (19) merupakan pengacuan endofora karena acuan kata keterangan tersebut berasal dari dalam teks itu. Selanjutnya, pengacuan kata kala itu pada penggalan cerpen (19) bersifat anaforis karena satuan lingual mengacu pada satuan lingual yang mendahuluinya.

\section{Referensi Demonstratif dulu}

(20) Dia dikerangkeng semasa revolusi dan sesudah masa kemerdekaan bekerja di penjara tempat dia dikerangkeng dulu. (Sepotong Kaki untuk Ayah)

Pada penggalan cerpen (20) terdapat bentuk referensi demonstratif dulu. Kata keterangan tersebut digunakan untuk menunjukan waktu, yaitu masa lampau ketika Ayah dari tokoh Aku dikerangkeng dalam penjara semasa revolusi. Kata keterangan waktu dulu pada penggalan cerpen (20) merupakan pengacuan endofora karena acuan kata keterangan tersebut berasal dari dalam teks itu. Selanjutnya, pengacuan kata dulu pada penggalan cerpen (20) bersifat anaforis karena satuan lingual mengacu pada satuan lingual yang mendahuluinya.

\section{Referensi Demonstratif siang itu}

(21) Sedangkan suami keempat bertahan beberapa bulan saja karena di suatu siang seorang wanita datang ke rumahnya dan mengaku sebagai istri dari suaminya.
Perang mulut seketika bergejolak di teras rumah. Siang itu juga secara tidak resmi, perempuan empat puluh tahunan itu kembali menjanda. (Balada Cun dan Suami Barunya)

Pada penggalan cerpen (21) terdapat bentuk referensi demonstratif siang itu. Kata keterangan tersebut digunakan untuk menunjukan waktu, yaitu suatu siang ketika seorang wanita datang ke rumah Cun untuk mengatakan bahwa suami Cun adalah suaminya. Kata keterangan waktu siang itu pada penggalan cerpen (21) merupakan pengacuan endofora karena acuan kata keterangan tersebut berasal dari dalam teks itu. Selanjutnya, pengacuan kata siang itu pada penggalan cerpen (21) bersifat anaforis karena satuan lingual mengacu pada satuan lingual yang mendahuluinya.

\section{Referensi Demonstratif sore itu}

(22) Cun tidak segan menggulinggulingkan badannya di teras rumah sore

itu. Urat malunya telah putus ditebas kenyataan. (Balada Cun dan Suami Barunya)

Pada penggalan cerpen (21) terdapat bentuk referensi demonstratif sore itu. Kata keterangan tersebut digunakan untuk menunjukan waktu, yaitu suatu sore ketika Cun sedang mengguling-gulingkan badannya di teras rumah. Kata keterangan waktu sore itu pada penggalan cerpen (21) merupakan pengacuan endofora karena acuan kata keterangan tersebut berasal dari dalam teks itu. Selanjutnya, pengacuan kata sore itu pada penggalan cerpen (21) bersifat anaforis karena satuan lingual mengacu pada satuan lingual yang mendahuluinya.

\section{Referensi Demonstratif hari itu}

(23) Si Inga, yang tak lain adalah adik kandung Cun sedang berkemas di kamarnya, tepat di sebelah rumah Cun. Hari itu, ia begitu bahagia. $\mathrm{Da}$ Ji akan 
mengajaknya pindah ke desa lain. Mereka akan memulai hidup baru. Yang tidak ada Cun-nya. (Balada Cun dan Suami Barunya)

Pada penggalan cerpen (23) terdapat bentuk referensi demonstratif hari itu. Kata keterangan tersebut digunakan untuk menunjukan waktu, yaitu suatu hari dimana Inga tengah bersiap-siap untuk pergi bersama Da Ji yang tak lain adalah suami kakak kandungnya. Kata keterangan waktu hari itu pada penggalan cerpen (23) merupakan pengacuan endofora karena acuan kata keterangan tersebut berasal dari dalam teks itu. Selanjutnya, pengacuan kata hari itu pada penggalan cerpen (23) bersifat anaforis karena satuan lingual mengacu pada satuan lingual yang mendahuluinya.

\section{Referensi Demonstratif hari ini}

(24) Pohon maple itu kembali dipukulnya. Bahkan kali ini menggunakan kepala. Aku tak mungkin melompat ke sungai itu dan menolong atau setidaknya menghentikan tingkahnya. Tapi pekerjaanku menumpuk dan hari ini mesti kuselesaikan. (Tepi Shire)

Pada penggalan cerpen (24) terdapat bentuk referensi demonstratif hari ini. Kata keterangan tersebut digunakan untuk menunjukan waktu yang mengacu pada hari yang tengah dilalui oleh tokoh Aku ketika ia sedang duduk di tepi sungai Shire sambil berupaya menyelesaikan pekerjaanya, namun mendapatkan gangguan dari seseorang yang tengah sibuk melukai dirinya sendiri di seberang sungai. Kata keterangan waktu hari ini pada penggalan cerpen (24) merupakan pengacuan endofora karena acuan kata keterangan tersebut berasal dari dalam teks itu. Selanjutnya, pengacuan kata hari ini pada penggalan cerpen (24) bersifat anaforis karena satuan lingual mengacu pada satuan lingual yang mendahuluinya.

\section{Referensi Demonstratif di sana}

(25) Seperti sebatang pohon akarnya begitu kuat. Setelah badai menerpanya, setelah seluruh daunnya ranggas, pokoknya kering seperti taka da harapan hidup, kini pucuk-pucuknya tumbuh. Secercah sinar dari timur di sana arah kehidupan dimulai, ke sana arah tubuh disujudkan, tempat para hyang bersemayam, kiblat kebaktian dan sujud kepada Ilahi. (Sepotong Kaki untuk Ayah)

Pada penggalan cerpen (25) terdapat bentuk referensi demonstratif di sana. Kata keterangan tersebut digunakan untuk menunjukan tempat, yaitu arah timur dimana kehidupan dimulai dari sana. Kata keterangan tempatdi sana pada penggalan cerpen (25) merupakan pengacuan endofora karena acuan kata keterangan tersebut berasal dari dalam teks itu. Selanjutnya, pengacuan kata di sana pada penggalan cerpen (25) bersifat anaforis karena satuan lingual mengacu pada satuan lingual yang mendahuluinya.

\section{Referensi Demonstratif $d i$ sini}

(26) Kadang di tempat tinggal, aku merasa tidak mengenal siapa tetanggaku karena satu dan lain hal. Kehidupan di sini begitu soliter. (Tepi Shire)

Pada penggalan cerpen (26) terdapat bentuk referensi demonstratif di sini. Kata keterangan tersebut digunakan untuk menunjukan tempat yaitu tempat tinggal tokoh Aku yang terasa begitu soliter. Kata keterangan tempatdi sini pada penggalan cerpen (26) merupakan pengacuan endofora karena acuan kata keterangan tersebut berasal dari dalam teks itu. Selanjutnya, pengacuan kata di sini pada penggalan cerpen (26) bersifat anaforis karena satuan lingual mengacu pada satuan lingual yang mendahuluinya. 


\section{Referensi Demonstratif ke sana}

(27) Aku tak mengerti mengapa ia melakukan hal itu. Ia teriakkan kata itu lagi.

Rasanya aku ingin mendekat dan menanyakan banyak hal, tapi hatiku menginginkan agar aku tak peduli. Lagi untuk mendekat ke sana rasanya tidak mungkin. Kami dipisahkan sungai. (Tepi Shire)

Pada penggalan cerpen (27) terdapat bentuk referensi demonstratif ke sana. Kata keterangan tersebut digunakan untuk menunjukan tempat, yaitu seberang sungai Shire, di tempat itulah seorang tukang sapu sibuk melukai dirinya sendiri sambil berteriak-teriak sehingga memecah konsentrasi tokoh Aku. Kata keterangan tempatke sana pada penggalan cerpen (27) merupakan pengacuan endofora karena acuan kata keterangan tersebut berasal dari dalam teks itu. Selanjutnya, pengacuan kata ke sana pada penggalan cerpen (27) bersifat kataforis karena satuan lingual mengacu pada satuan lingual yang mengikutinya.

\section{Referensi Demonstratif ke mana}

(28) Kemudian saya menemukan kayu dari sepotong pohon kayun, pohon keinginan, yang tumbuh di jagat diri, menjadi kaki pengganti kaki ayah yang hilang dan menjadi bagian ke mana pun dia pergi.

(Sepotong Kaki untuk Ayah)

Pada penggalan cerpen (28) terdapat bentuk referensi demonstratif ke mana. Kata keterangan tersebut digunakan untuk menunjukan tempat, yaitu arah yang menjadi tujuan dari perjalanan ayah tokoh Aku. Kata keterangan tempatke mana pada penggalan cerpen (28) merupakan pengacuan endofora karena acuan kata keterangan tersebut berasal dari dalam teks itu. Selanjutnya, pengacuan kata ke mana pada penggalan cerpen (28) bersifat kataforis karena satuan lingual mengacu pada satuan lingual yang mengikutinya.

\section{Referensi Demonstratif sana}

(29) Tiba-tiba saja bayanganku terbang jauh ke kampung, di Priangan sana. Orang itu seumur kakekku. (Tepi Shire)

Pada penggalan cerpen (29) terdapat bentuk referensi demonstratif sana. Kata keterangan tersebut digunakan untuk menunjukan tempat, yaitu kampong halaman tokoh Aku di daerah Priangan. Kata keterangan tempatsana pada penggalan cerpen (29) merupakan pengacuan endofora karena acuan kata keterangan tersebut berasal dari dalam teks itu. Selanjutnya, pengacuan kata sana pada penggalan cerpen (29) bersifat anaforis karena satuan lingual mengacu pada satuan lingual yang mendahuluinya.

\section{Referensi Demonstratif ini}

(30) "Sungguh...negeri ini sangat kehilangan putra terbaik bangsa. Tuan GragGaz telah membawa menuju horizon cahaya," kata Sarvantina Tunner, Ketua Majelis Tinggi Perwakilan Rakyat Republik Garpallo, di akhir pidato sambutannya.

Pada penggalan cerpen (30) terdapat bentuk referensi demonstratif ini. Kata keterangan tersebut digunakan untuk menunjukan tempat, yaitu negeri republik Garpallo. Kata keterangan tempat inipada penggalan cerpen (30) merupakan pengacuan endofora karena acuan kata keterangan tersebut berasal dari dalam teks itu, acuan dari kata ini telah berulang kali ditunjukkan pada paragraf terdahulu. Selanjutnya, pengacuan kata ini pada penggalan cerpen (30) bersifat anaforis karena satuan lingual mengacu pada satuan lingual yang mendahuluinya. 


\section{Referensi Demonstratif itu}

(31) Bacalah karya-karya Munro yang dapat kau beli di toko buku (akan tidak etis jika menyebutkan nama toko buku itu). Bacalah dan bacalah. (Saran Seorang Pengarang)

Pada penggalan cerpen (31) terdapat bentuk referensi demonstratif itu. Kata keterangan tersebut digunakan untuk menunjukan tempat, yaitu sebuah toko buku tempat membeli buku karya-karya Munro. Kata keterangan tempatitu pada penggalan cerpen (31) merupakan pengacuan endofora karena acuan kata keterangan tersebut berasal dari dalam teks itu. Selanjutnya, pengacuan kata itu pada penggalan cerpen (31) bersifat anaforis karena satuan lingual mengacu pada satuan lingual yang mendahuluinya.

\section{Referensi Komparatif}

Bentuk kohesi gramatikal referensi komparatif yang ditemukan dalam koleksi cerita pendek Kompas Minggu 2015 edisi bulan Maret dapat dikatakan sangat terbatas. Hal tersebut dikarenakan dari kelima cerpen yang dikaji, penulis hanya menemukan satu bentuk referensi komparatif yaitu seperti. Referensi ini hanya ditemukan pada cerpen berjudul Saran Seorang Pengarang dan Balada Cun dan Suami Barunya yang dilampirkan pada tabel berikut ini.

Tabel 3. Jumlah Penggunaan Bentuk Kohesi Gramatikal Referensi Komparatif pada Cerita Pendek Kompas

\begin{tabular}{|c|c|c|c|c|c|c|}
\hline \multirow[b]{2}{*}{ No } & \multirow[b]{2}{*}{$\begin{array}{c}\text { Bentuk } \\
\text { Referensi } \\
\text { Demonstratif }\end{array}$} & \multicolumn{5}{|c|}{ Judul Cerpen } \\
\hline & & $\begin{array}{c}\text { Saran Seorang } \\
\text { Pengarang }\end{array}$ & $\begin{array}{c}\text { Kebohongan Itu } \\
\text { Manis, } \\
\text { Vardhaz̧ }\end{array}$ & $\begin{array}{l}\text { Tepi } \\
\text { Shire }\end{array}$ & $\begin{array}{c}\text { Sepotong } \\
\text { Kaki Untuke } \\
\text { Ayah }\end{array}$ & $\begin{array}{c}\text { Balada Cun } \\
\text { dan Suami } \\
\text { Barunya }\end{array}$ \\
\hline
\end{tabular}

$\begin{array}{lcc}1 & \text { Seperti } & 1 \\ \text { Referensi Demonstratif seperti }\end{array}$

(32) Menjadi pengarang sebaiknya tidak berangkat dari pemikiran seperti itu. Jadikanlah mengarang itu seperti berolahraga. Berolahraga untuk sehat bukan untuk menjadi juara PON, SEA Games, Asian Games atau Olimpiade. Artinya, selagi masih kreatif menulislah terus. Selagi sehat teruslah berolahraga. (Saran Seorang Pengarang)

Satuan lingual seperti pada penggalan cerpen (32) diatas mengacu pada perbandingan persamaan antara tindakan mengarang dengan berolahraga. Pengacuan kata seperti pada penggalan cerpen (32) merupakan pengacuan endofora karena acuan kata seperti berasal dari dalam teks itu sendiri. Selanjutnya pengacuan kata seperti tersebut bersifat kataforis karena satuan lingual mengacu pada satuan lingual yang mengikutinya.

\section{SIMPULAN}

Penggunaan bentuk referensi yang bervariasi dapat dikatakan mampu menghidupkan suasana dalam cerita. Penggunaannya pun mampu menunjukkan kepada para pembaca tentang ciri khas seorang pengarang dalam menciptakan karyanya. Dalam menciptakan sebuah karya tentunya para pengarang memiliki banyak pertimbangan, salah satunya dalam memilah penggunaan bentuk referensi. Berkenaan dengan hal tersebut, berdasarkan dari hasil kajian yang telah dilakukan dapat disimpulkan bahwa kohesi gramatikal referensi yang ditemukan dalam koleksi cerita pendek Kompas Minggu 2015 edisi bulan Maret yang mencakup lima buah cerpen berjudul Saran Seorang Pengarang karya Sori Siregar, Kebohongan Itu Manis, Vardhaz̧ karya Indra Tranggono, 
Tepi Shire karya Tawakal M. Iqbal, Sepotong Kaki untuk Ayah karya I Ngoman Wirata, dan Balada Cun dan Suami Barunya karya Dedi Supendra berbentuk referensi persona, referensi demonstratif, dan referensi komparatif.

Bentuk kohesi gramatikal referensi persona yang ditemukan adalah referensi persona I terdiri atas aku, saya, ku-, -ku, kita, dan kami. Referensi persona IIterdiri atas kamu, kau, -mu,dan kalian. Serta referensi persona IIIterdiri atasia, dia, -nya, beliau, dan mereka. Bentuk kohesi gramatikal referensi demonstratif yang ditemukan berupa kini, sekarang, saat ini, kala itu, dulu, siang itu, sore itu, hari itu, hari ini, di sana, di sini, ke sana, ke mana, sana, ini, dan itu. Serta, satu bentuk kohesi gramatikal referensi komparatif yang ditemukan adalah seperti.

\section{DAFTAR RUJUKAN}

Alwi et al. (1998), Tata Bahasa Baku Bahasa Indonesia. Jakarta: Balai Pustaka.

Aflahah. (2012). Kohesi dan Koherensi dalam Wacana. Aksara, 2(1), 9-18.
Baryadi, P.(2002). Dasar-dasar Analisis Wacana dalam Ilmu Bahasa. Jogjakarta: Pustaka Gondho Suli.

Djajasudarma, F. (2006). Wacana: Pemabaman dan Hubungan Antarunsur. Bandung: Refika Aditama.

Eriyanto. (2009). Analisis Wacana: Pengantar Analisis Teks Media. Yogyakarta: PT. LKiS Printing Cemerlang.

Indrayanti, N. (2013). Analisis Kohesi Gramatikal Pengacuan Pada Cerpen Surat Kabar KOMPAS Edisi Maret 2013. Surakarta: Universitas Muhammadiyah Surakarta.

Lubis, A. H.H (1991). Analisis Wacana Pragmatik. Bandung: Angkasa.

Muhyidin. (2012). Kohesi Gramatikal Pengacuan dalam Cerpen Pembelaan Bah Bela Karya Moh. Wan Anwar. Jurnal Pendidikan Bahasa dan Sastra, 12(2).

Rani, A., et al. (2004). Analisis Wacana: Sebuah Kajian Bahasa dalam Pemakaian. Malang: Bayumedia Publishing.

Wicaksono, A. (2017). Pengkajian Prosa Fiksi (Edisi Revisi). Yogyakarta: Penerbit Garudhawaca. 